\title{
Studi Kelayakan Bisnis Telur Asin H-Organik
}

\author{
Opan Arifudin' ${ }^{1}$, Yayan Sofyan², Rahman Tanjung ${ }^{3}$ \\ ${ }^{1}$ STEI Al-Amar Subang, opan.arifudin@yahoo.com \\ ${ }^{2}$ STIE Muhammadiyah Bandung, Yayansofyan1971@yahoo.co.id \\ ${ }^{3}$ STIT Rakeyan Santang Karawang, rahmantanjung1981@ gmail.com
}

\begin{abstract}
ABSTRAK
Dalam rangka meningkatkan produktifitas dan efektivitas perusahaan, perlu diadakannya sebuah penelitiaan Studi kelayakan bisnis yang berguna untuk meneliti dan menelaah berbagai aspek yang mendukung dalam pengembangan perusahaan. Untuk itu penelitian ini bertujuan untuk melihat studi kelayakan bisnis pada sektor bisnis yang bergerak dalam bidang produksi dan penjualan telur asin. Penelitian ini menggunakan jenis penelitian deskriptif. Penelitian ini akan menguji bagaimana kelayakan Telur asin H-Organik, yaitu penelitian yang dilakukan untuk mengetahui nilai variabel mandiri, baik satu variabel atau lebih tanpa membuat perbandingan atau menghubungkan dengan variabel lain. Hasil penelitian menunjukan : 1) Dilihat dari aspek pemasaran. ramalan permintaan pasar terhadap telur asinsetelah dianalisis. ternyata permintaan pasar sangat fluktuatif. begitu juga dengan potensi pasar yang ternyata menunjukkan adanya permintaan yang belum terpenuhi oleh perusahaan. Dengan demikian perusahaan berkesempatan untuk dapat meningkatkan kapasitas produksinya serta menambah toko distribusi penjualan, 2) Lokasi yang cukup strategis memungkinkan perusahaan untuk dapat meningkatkan efisiensi. melalui pengelolaan bahan baku. serta mengelola ketersediaan tenaga kerja yang merupakan keuntungan bagi perusahaan Telur asin H-Organik, 3) Dengan adanya cabang toko baru sebagai bentuk perluasan proses pemasaran. serta berpengaruh dalam meningkatkan tingkat penjualan layak untuk direalisasikan, 4) Dengan perkembangan yang dihadapai perusahaan. maka sudah seharusnya struktur organisasi dan system manajemen yang diterapkan harus diperbaiki sehingga sesuai dengan tuntutan perkembangan perusahaan, dan 5) Dalam melakukan proses produksi. perusahaan tidak mengakibatkan atau menghasilkan limbah yang dapat membahayakan masyarakat sekitar sehingga aman bagi lingkungan. Hal ini menambah nilai positif dan pencitraan bagi perusahaan dimata masyarakat.
\end{abstract}

Kata kunci : Kelayakan, Bisnis

\section{ABSTRACT}

In order to increase the productivity and effectiveness of the company, it is necessary to hold a business feasibility study that is useful for researching and examining various aspects that support the development of the company. For this reason, this study aims to look at business feasibility studies in the business sector engaged in the production and sale of salted eggs. This research uses descriptive research. This study will examine how the feasibility of H-Organic Salted Eggs, namely research conducted to determine the value of independent variables, either one or more variables without making comparisons or connecting with other variables. The results showed: 1) Viewed from the marketing aspect. the forecast of market demand for insured eggs has been analyzed. it turns out that market demand is very volatile. as well as the market potential which turns out to indicate a demand that has not been fulfilled by the company. Thus the company has the opportunity to be able to increase its production capacity and increase sales distribution stores, 2) Strategic location that allows the company to be able to increase efficiency. through managing raw materials. and managing the availability of labor which is a 
benefit for the H-Organic Salted Eggs company, 3) With the existence of a new store branch as a form of expansion of the marketing process. as well as influential in increasing the level of sales feasible to be realized, 4) With developments facing the company. then the organizational structure and management system that should be applied must be improved so that it is in accordance with the demands of the company's development, and 5) In conducting the production process. the company does not produce or produce waste that can endanger the surrounding community so that it is safe for the environment. This adds to the positive value and image of the company in the eyes of the community.

Keywords: Appropriateness, Business

Naskah diterima: 29-08-2020, direvisi: 14-07-2020, diterbitkan: 01-09-2020

\section{PENDAHULUAN}

Dampak Ekonomi bulan maret tahun 2020 sangat berpengaruh terhadap perkembangan bisnis Indonesia. Dalam hal ini Pemerintah telah mencoba mencanangkan sistem perdagangan bebas serta menerapkan berbagai kebijakan untuk dapat memperbaiki perekonomian.

Menurut (Arifudin, 2020) bahwa perkembangan dalam dunia usaha di Indonesia saat ini yang semakin cepat dan pesat berakibat juga pada perubahan budaya. Sehingga organisasi dituntut untuk mempunyai budaya yang membedakan dengan organisasi lain yang sejenis.

Namun pada kenyataannya Indonesia masih berada dalam krisis yang multidimensi. Krisis yang terus melanda mengakibatkan banyak bermunculan jenis usaha baru. jenis usaha tersebut akhirnya bersaing untuk mendapatkan market share yang luas. Dalam kondisi seperti ini perusahaan tentunya harus berani menghadapi berbagai resiko yang sangat berat dan mereka harus mampu bertahan dalam iklim persaingan yang ketat. Agar perusahaan tersebut dapat bertahan. maka diperlukan sumber daya yang mampu bersaing dan mampu memberikan kepuasan yang lebih bagi konsumen. Hal ini sejalan dengan pendapat (Arifudin, 2019) bahwa faktor manusia adalah salah satu dari kunci keberhasilan perusahaan dalam mencapai tujuan.

Salah satu perusahaan yang memiliki persaingan yang sangat ketat dalam menjalankan bisnisnya yaitu perusahaan telur asin. Perusahaan ini berusaha bersaing untuk dapat tetap eksist dalam menghadapi persaingan dan kondisi ekonomi yang tidak menentu. Telur asin telah menjadi Icon jenis makanan yang digemari baik di dalam maupun diluar daerah Bandung. Atas dasar inilah studi kelayakan bisnis mencoba untuk mengamati sektor bisnis yang bergerak dalam bidang prodiksi dan penjualan telur asin. salah satu perusahaan telur asin yang tetap eksis dalam menghadapi tantangan ekonomi dan persaingan yaitu perusahaan Telur asin H-Organik.

Pemilihan objek penelitian pada perusahaan Telur asin H-Organik mengingat perusahaan ini merupakan perusahaan yang sudah lama. Sehingga dapat dilihat bagaimana perusahaan ini berinovasi dan terus eksis ditengah bermunculan pemain-pemain baru sebagai pesaing. Pihak manajemen harus mampu membuat formulasi strategi baru dan efektif untuk memenangkan pasar. Hal ini sejalan dengan pendapat (Echo Perdana Kusumah, Disman, 2020) bahwa ada berbagai faktor-faktor yang mempengaruhi keterlibatan merek, sehingga berujung kepada kepuasan konsumen dan kunjungan kembali.

\section{KAJIAN LITERATUR \\ a. Studi Kelayakan Bisnis}

Proyek investasi pada umumnya membutuhkan dana yang tidak sedikit dan berpengaruh bagi perusahaan dalam jangka waktu yang panjang, karena itu perlu dilakukan studi kelayakan bisnis agar dana yang telah diinvestasikan tidak terbuang percuma.

Menurut (Arifudin. O. \& Rusmana. F., 2020) bahwa organisasi akan berusaha 
untuk meningkatkan kemampuannya menyelenggarakan semua fungsi organisasi dengan tingkat efesiensi dan efektivitas yang tinggi perwujudan situasi demikian, setiap organisasi menghadapi berbagai tantangan internal yang tidak kalah pentingnya dengan berbagai tantangan yang sifatnya eksternal.

Studi kelayakan bisnis dapat diartikan sebagai penelitian tentang akan didirikan atau perluasan suatu proyek guna mengetahui apakah layak atau tidaknya proyek tersebut dilaksanakan atau menguntungkan. Studi kelayakan bisnis bila dilakukan secara professional akan dapat berperan penting dalam proses pengambilan keputusan investasi.

Menurut (Jakfar, 2012), Kelayakan artinya penelitian yang dilakukan secara mendalam untuk menentukan apakah usaha yang akan dijalankan akan memberikan manfaat yang lebih besar dibandingkan dengan biaya yang akan dikeluarkan. Sedangkan bisnis adalah usaha yang dijalankan yang tujuan utamanya untuk memperoleh keuntungan. Dengan demikian, dapat disimpulkan bahwa pengertian Studi Kelayakan Bisnis (SKB) adalah suatu kegiatan yang mempelajari secara mendalam tentang suatu usaha atau bisnis yang akan dijalankan, dalam rangka menentukan layak atau tidak usaha tersebut dijalankan.

Menurut (Sunyoto, 2014), studi kelayakan bisnis merupakan penelitian terhadap rencana bisnis yang tidak hanya menganalisis layak atau tidaknya bisnis dibangun, tetapi juga saat dioperasionalkan secara rutin dalam rangka pencapaian keuntungan yang maksimal untuk waktu yang tidak ditentukan. Studi kelayakan biasanya digolongkan menjadi dua bagian yang berdasarkan pada orientasi yang diharapkan oleh satu perusahaan yaitu berdasarkan orientasi laba dan orientasi tidak pada laba (sosial).

Menurut (Jakfar, 2012), ada lima tujuan dari studi kelayakan bisnis, yaitu :
1. Menghindari resiko kerugian. Untuk mengatasi risiko kerugian dimasa yang akan datang, karena di masa yang akan datang ada semacam kondisi ketidakpastian. Kondisi ini ada yang dapat diramalkan akan terjadi atau memang dengan sendirinya terjadi tanpa dapat diramalkan. Dalam hal ini, fungsi studi kelayakan adalah untuk meminimalkan risiko yang tidak kita inginkan, baik risiko yang dapat dikendalikan maupun yang tidak dapat dikendalikan.

2. Memudahkan perencanaan. Perencanaan meliputi berapa jumlah dana yang diperlukan, kapan usaha akan dijalankan, dimana lokasi proyek akan dibangun, siapa-siapa yang akan melaksanakannya, berapa besar keuntungan yang akan diperoleh serta bagaimana mengawasi jika terjadi penyimpangan.

3. Memudahkan pelaksanaan pekerjaan. Dengan adanya berbagai rencana yang sudah disusun akan sangat memudahkan pelaksanaan bisnis. Para pelaksana yang mengerjakan bisnis tersebut telah memiliki pedoman yang harus dikerjakan.Kemudian pengerjaan usaha dapat dilakukan secara sistematik, sehingga tepat sasaran dan sesuai dengan rencana yang sudah disususn.Rencana yang sudah disusun dijadikan acuan dalam mengerjakan setiap tahap yang sudah direncanakan.

4. Memudahkan pengawasan. Dengan telah dilaksanakannya suatu usaha atau proyek sesuai dengan rencana yang sudah disusun, maka akan memudahkan perusahaan untuk melakukan pengawasan terhadap jalannya usaha. Pengawasan ini perlu dilakukan agar pelaksanaan usaha tidak melenceng dari rencana yang telah disusun. 
5. Memudahkan pengendalian. Jika dalam pelaksanan pekerjaan telah dilakukan pengawasan, maka apabila terjadi suatu penyimpangan akan mudah terdeteksi, sehingga akan dapat dilakukan pengendalian atas penyimpangan tersebut. Tujuan pengendalian adalah untuk mengembalikan pelaksanaan pekerjaan yang melenceng ke rel yang sesungguhnya, sehingga pada akhirnya tujuan perusahaan akan tercapai.

\section{b. Penjualan}

Penjualan menurut (Westwood, 2006) adalah konsep lugas yang diantaranyaberupa usaha membujuk pelanggan unuk sebuah produk. Upaya itu meliputi "pesanan hari ini". Meski demikian kegiatan ini hanyalah salah satu aspek dari pemasaran. Kegiatan penjualan terdiri atas transaksi barang atau jasa. Pejualan dapat dilaksanakan melalui penjualan tunai ataupun penjualan kredit.

Tujuan dari manajemen penjualan adalah untuk mencapai hasil perkembangan bisnis seperti yang telah direncanakan dengan memotivasi anggota tim penjualan untuk menampilkan kemampuan terbaik mereka.

Manajemen penjualan merupakan suatu proses yang tetap dan berulang dalam siklus kehidupan ekonomi. Adapun faktor-faktor yang mempengaruhi Penjualan menurut (DH, 2009) faktorfaktor yang mempengaruhi kegiatan penjualan yaitu:

1. Kondisi dan kemampuan penjual Transaksi jual-beli atau pemindahan hak milik secara komersial atas barang dan jasa itu pada prinsipnya melibakan dua pihak, yaitu penjual sebagai pihak pertama dan pembeli sebagai pihak kedua. Penjual harus dapa meyakinkan kepada embeli agar dapat berhasil mencapai sasaran penjualan yang diharapkan oleh konsumen. Penjual harus memahami beberapa masalah penting yang sangat berkaitan yakni:

a) Jenis dan karakteristik barang yang ditawarkanan

b) Harga Produk

c) Syarat penjualan, seperi: pembayaran, penghantaran barang, pelayanan purna jual, garansi dan sebagainya.

2. Kondisi pasar

Pasar sebagai kelompok pembeli atau pihak yang menjadi sasaran dalam penjualan, dapat pula mempengaruhi kegiatan penjualannya. Adapun faktor-faktor kondisi pasar yang perlu diperhatikan adalah:

a) Jenis pasarnya, apakah pasar konsumen, pasar industri, pasar penjual, ppasar pemerintahan ataukah pasar internasional

b) Kelompok pembeli atau segmen pasarnya

c) Daya belinya

d) Frekuensi pembeliannya

e) Keinginan kebutuhan

3. Modal

Apabila barang yang dijual belum diketahui oleh pembeli maka penjual harus memperkenalkan dulu atau membawa barangnya ke tempat pembeli. Untuk melaksanakan maksud tersebut diperlukan adanya sarana serta usaha, seperti: alat transport, tempat peragaan baik di dalam perusahaan maupuun diluar perusahaan, usaha promosi, dan sebagainya. Semua ini hanya dapat dilakukan apabila penjual memilik sejumlah modal untuk itu.

4. Kondisi Organisasi Perusahaan

Pada perusahaan besar bagian penjualan ditangani oleh orang yang telah ahli dibidang penjualan. Lain halnya dengan usaha kecil yang dimana bagian penjualanya ditangani oleh orang yang juga melakukan fungsi-fungsi lain hal ini disebabkan karena jumlah tenaga kerjanya lebih sediki, sisem organisasinya lebih sederhana, 
masalah yang dihadapi serta sarana yang dimilikinya juga ditangani sendiri oleh pemimpinan dan tidak diberikan kepada orang lain.

5. Faktor lain yang mempengaruhi penjualan seperti periklanan, peragaan, kampanye, dan pemberian hadiah.

Untuk melaksanakan promosi diperlukan dana yang tidak sedikit dan hanya dapat dilakukan oleh perusahaan yang bermodal kuat, kegiatan ini dilakukan secara rutin, namun sebagian perusahaan lebih berpegang pada prinsip "paling penting membuat barang yang berkualitas baik. Bilamana prinsip tersebut dilaksanakan maka diharapkan pembeli akan membeli barang yang sama.
Jadi, dalam melakukan kegiatan pasar terhdapat lima faktor yang mempengaruhi terpenuhinya keinginan konsumen akan suatu barang yang di produksi maupun dijual oleh produsen.

\section{METODE PENELITIAN}

Penelitian ini menggunakan jenis penelitian deskriptif. Penelitian ini akan menguji bagaimana kelayakan Telur asin $\mathrm{H}$ Organik. Yaitu penelitian yang dilakukan untuk mengetahui nilai variabel mandiri, baik satu variabel atau lebih tanpa membuat perbandingan atau menghubungkan dengan variabel lain." Tujuan dari penelitian deskriptif ialah untuk mendeskripsikan atau menggambarkan hasil penelitian berdasarkan fakta-fakta yang ada berupa data-data yang diperoleh dari survei lapangan.

\section{PEMBAHASAN}

\section{Perhitungan Rasio Aktifitas}

$$
\text { Turn over asset }=\frac{\text { Penjualan }}{\text { Total Aktiva }}
$$

Tabel 1 Perhitungan Turn Over Asset

\begin{tabular}{|l|c|c|c|c|c|}
\hline \multirow{2}{*}{ Keterangan } & \multicolumn{5}{|c|}{ Tahun } \\
\cline { 2 - 6 } & $\mathbf{2 0 1 5}$ & $\mathbf{2 0 1 6}$ & $\mathbf{2 0 1 7}$ & $\mathbf{2 0 1 8}$ & $\mathbf{2 0 1 9}$ \\
\hline Penjualan & $440,883,500$ & $469,536,000$ & $509,175,000$ & $550,420,000$ & $604,257,500$ \\
\hline $\begin{array}{l}\text { Total } \\
\text { Aktiva }\end{array}$ & $1,168,650,000$ & $280,016,713$ & $551,186,366$ & $846,577,942$ & $1,167,010,429$ \\
\hline $\begin{array}{l}\text { Turn Over } \\
\text { Asset }\end{array}$ & 0.3772588 & 1.6768142 & 0.923780107 & 0.650170495 & 0.517782434 \\
\hline
\end{tabular}

Sumber: Olahan data 2019

Dari perhitungan di atas dapat 37 kali penggunaan aktiva dan ini diketahui bahwa untuk tahun 2015 menandakan aktiva yang yang efektivitas penggunaan aktiva dalam digunakan mempunyai tingkat menciptakan penjualan adalah sebesar $0 . \quad$ efektivitas sebesar 0.37 .

\section{Perhitungan Rasio Liquiditas}

$$
\text { Likuiditas }=\frac{\text { Aktiva Lancar }}{\text { Hutang Lancar }} \times 100 \%
$$


Karena perusahaan tidak mempunyai

bahwa perusahaan sangat likuid. hutang lancar. maka dapat disimpulkan

\section{Perhitungan Rasio Solvabilitas}

\section{Debt to Equity Ratio = Total Hutang x 100\%}

Total Aktiva

Tabel 2 Perhitungan DER

\begin{tabular}{|c|r|r|r|r|r|}
\hline \multirow{2}{*}{ Keterangan } & \multicolumn{6}{|c|}{ Tahun } & $\mathbf{2 0 1 5}$ & $\mathbf{2 0 1 6}$ & $\mathbf{2 0 1 7}$ & $\mathbf{2 0 1 8}$ & $\mathbf{2 0 1 9}$ \\
\cline { 2 - 7 } & & & & & 0 \\
Total Hutang & 0 & 0 & 0 & 0 & 0 \\
\hline Total Aktiva & $1,168,650,000$ & $280,016,713$ & $551,186,366$ & $846,577,942$ & $1,167,010,429$ \\
\hline DER & $\mathbf{0 \%}$ & $\mathbf{0 \%}$ & $\mathbf{0 \%}$ & $\mathbf{0 \%}$ & $\mathbf{0 \%}$ \\
\hline
\end{tabular}

Sumber : Olahan data 2020

\section{Perhitungan Rasio Profitabilitas}

$$
\text { Return on Asset }=\underset{\text { Total aktiva }}{\text { EAT }} \times 100 \%
$$

Tabel 3 Perhitungan ROA

\begin{tabular}{|c|c|c|c|c|c|}
\hline \multirow{2}{*}{ Keterangan } & $\mathbf{5 0 1 5}$ & $\mathbf{2 0 1 6}$ & $\mathbf{2 0 1 7}$ & $\mathbf{2 0 1 8}$ & $\mathbf{2 0 1 9}$ \\
\cline { 2 - 7 } & & & & & \\
\hline EAT & $254,827,313$ & $271,169,653$ & $295,391,576$ & $320,432,487$ & $354,505,273$ \\
\hline Total Aktiva & $1,168,650,000$ & $280,016,713$ & $551,186,366$ & $846,577,942$ & $1,167,010,429$ \\
\hline ROA & $\mathbf{2 2 \%}$ & $\mathbf{9 7 \%}$ & $\mathbf{5 4 \%}$ & $\mathbf{3 8 \%}$ & $\mathbf{3 0 \%}$ \\
\hline
\end{tabular}

Sumber : Olahan data 2020

Dari hasil perhitungan ROA untuk tahun 2015 menunjukkan bahwa dari total aktiva yang dimiliki. perusahaan memberikan pengembalian sebesar $22 \%$.
Dan dari tahun ke tahun nilai ini terus mengalami peningkatan walaupun fluktutif. 


\section{Analisis Kelayakan Investasi}

\section{Perhitungan Proyeksi Payback Period (PP)}

\begin{tabular}{|c|r|r|}
\multicolumn{4}{|c|}{ Tabel 4 Perhitungan Pay Back Period } \\
\cline { 2 - 4 } & \multicolumn{1}{c|}{$\mathbf{C F}_{\mathbf{t}}$} & \multicolumn{1}{c|}{ CF Komulatif } \\
\hline Tahun Ke & $-422,060,600$ & $-422,060,600$ \\
\hline 1 & $\mathbf{( 1 4 9 , 7 5 8 , 2 8 7 )}$ & $(571,818,887)$ \\
\hline 2 & $\mathbf{1 3 8 , 8 8 6 , 3 6 6}$ & $(432,932,521)$ \\
\hline 3 & $\mathbf{4 5 1 , 7 5 2 , 9 4 2}$ & $18,820,421$ \\
\hline 4 & $\mathbf{7 8 9 , 6 6 0 , 4 2 9}$ & $808,480,850$ \\
\hline 5 & $\mathbf{1 , 1 6 1 , 1 6 5 , 7 0 2}$ & $1,969,646,552$ \\
\hline
\end{tabular}

Sumber : Olahan data 2020

$\mathrm{PP}=(\mathrm{n}-)-(\mathrm{CF}$ Komulatif -$) \frac{(n+)-(n-)}{(C F+)-(C F-)}$

$\mathrm{PP}=2-(-422,060,600) \quad\left(\frac{3-2}{18,820,421-(-432,932,521)}\right)$

$\mathrm{PP}=2+\underline{422,060,600}$

$451,752,942$

$\mathrm{PP}=2+0.93$

$\mathrm{PP}=2$ tahun 9 bulan 3 hari

Berdasarkan data di atas dapat diketahui kurang dari masa investasi selama 5 bahwa perusahaan mampu mengembalikan tambahan investasi dan modal kerja operasional tahun 2010 selama 2 tahun 9 bulan 3 hari atau tahun. Maka pengembangan usaha ini layak berdasarkan metode penilaian payback period.

2. Perhitungan Profitability Index (PI)

$\mathrm{PI}=\frac{\mathrm{NPV}}{\text { Investasi awal }}$

Tabel 5 Perhitungan Profitability Index (PI)

\begin{tabular}{|c|r|c|r|}
\hline Tahun Ke & \multicolumn{1}{|c|}{ CF $_{\mathbf{t}}$} & PVIFr.n (10\%) & \multicolumn{1}{c|}{ PV } \\
\hline 0 & $-422,060,600$ & 1 & $-422,060,600$ \\
\hline 1 & $(149,758,287)$ & 0.909 & $-136,130,283$ \\
\hline 2 & $138,886,366$ & 0.826 & $114,720,138$ \\
\hline
\end{tabular}

ISSN: 2355-0295, e-ISSN: 2549-8932

http://ejournal.bsi.ac.id/ejurnal/index.php/ecodemica 


\begin{tabular}{|l|r|l|r|}
\cline { 2 - 3 } 3 & $451,752,942$ & 0.751 & $339,266,459$ \\
\hline 4 & $789,660,429$ & 0.683 & $539,338,073$ \\
\hline 5 & $1,161,165,702$ & 0.621 & $721,083,901$ \\
\hline & Total & NPV & $\mathbf{1 , 1 5 6 , 2 1 7 , 6 8 8}$ \\
\hline
\end{tabular}

Sumber : Olahan data 2020

$$
\begin{aligned}
\mathrm{PI} & =\frac{1,156,217,688}{422,060,600} \\
& =2,74
\end{aligned}
$$

Nilai PI diatas menunjukkan bahwa jika proyek dilaksanakan. maka akan menghasilkan laba sebesar 2,74 kali lipat dari investasi yang ditamankan. Dan syarat kelayakan adalah jika PI $>1$.

3. Perhitungan Net Present Value (NPV)

$$
\mathrm{NPV}=\text { Total PV }-\mathrm{I}_{0}
$$

dari hasil perhitungan diketahui bahwa PI lebih besar dari satu . sehingga usaha ini layak untuk dikembangkan.

Tabel 6 Perhitungan Net Present Value

\begin{tabular}{|c|r|c|r|}
\hline Tahun Ke & \multicolumn{1}{|c|}{$\mathbf{C F}_{\mathbf{t}}$} & PVIFr.n (10\%) & \multicolumn{1}{c|}{ PV } \\
\hline 0 & $-422,060,600$ & 1 & $-422,060,600$ \\
\hline 1 & $(149,758,287)$ & 0.909 & $-136,130,283$ \\
\hline 2 & $138,886,366$ & 0.826 & $114,720,138$ \\
\hline 3 & $451,752,942$ & 0.751 & $339,266,459$ \\
\hline 4 & $789,660,429$ & 0.683 & $539,338,073$ \\
\hline 5 & $1,161,165,702$ & 0.621 & $721,083,901$ \\
\hline & Total & NPV & $\mathbf{1 , 1 5 6 , 2 1 7 , 6 8 8}$ \\
\hline
\end{tabular}

Sumber : Olahan data 2020

Dari hasil perhitungan dapat diketahui. bahwa NPV perusahaan Telur asin $\mathrm{H}$ Organik bernilai positif. ini berarti

bahwa usaha ini layak untuk dikembangkan.

\section{Phitungan Internal Rate of Return (IRR)}

Net Present Value $=$ Present Value Investasi

Dari perhitungan cash flow dapat kita ketahui bahwa cash flow yang terjadi untuk tiap tahunnya adalah sebagai berikut: 
Tabel 7 Perhitungan Present Value

\begin{tabular}{|c|c|}
\hline Tahun Ke & $\mathbf{C F}_{\mathbf{t}}$ \\
\hline 0 & $-422,060,600$ \\
\hline 1 & $(149,758,287)$ \\
\hline 2 & $138,886,366$ \\
\hline 3 & $451,752,942$ \\
\hline 4 & $789,660,429$ \\
\hline 5 & $1,161,165,702$ \\
\hline
\end{tabular}

berdasarkan perhitungan dengan dengan cara Trial and error seperti langkah-langkah seperti di atas. maka diperoleh nilai IRR $53 \%$. Atau biasa

sebagai berikut:

Tabel 8 Perhitungan IRR

\begin{tabular}{|c|r|c|c|c|c|}
\hline Tahun & Net Cash Flow & PVIF 10 \% & PVCF 1 & $\begin{array}{c}\text { PVIF 20 } \\
\text { \% }\end{array}$ & PVCF 2 \\
\hline 0 & $-422,060,600$ & 0.909 & $-422,060,600$ & 1 & $-422,060,600$ \\
\hline 1 & $(149,758,287)$ & 0.826 & $114,720,138$ & 0.833 & $-124,748,653$ \\
\hline 2 & $138,886,366$ & 0.751 & $339,266,459$ & 0.694 & $96,387,138$ \\
\hline 3 & $451,752,942$ & 0.683 & $539,338,073$ & 0.579 & $261,564,953$ \\
\hline 4 & $789,660,429$ & 0.621 & $721,083,901$ & 0.482 & $380,616,327$ \\
\hline 5 & $1,161,165,702$ & 0.909 & $-136,130,283$ & 0.402 & $466,788,612$ \\
\hline & & NPV & $\mathbf{1 , 1 5 6 , 2 1 7 , 6 8 8}$ & NPV & $\mathbf{1 , 0 8 0 , 6 0 8 , 3 7 7}$ \\
\hline
\end{tabular}

Sumber : Olahan data 2020

$\mathrm{IRR}=\mathrm{i} 1+(\mathrm{i} 2-\mathrm{i} 1)(\mathrm{PVCF} 1):$

$(\mathrm{PVCF} 1-\mathrm{PFCV} 2)=10 \%+(20 \%-10$

\%) $(1,156,217,688)$

$(1,156,217,688-1,080,608,377)=10 \%$

$+10 \% .15 .29200138$

$=35,29 \%$

Syarat kelayakan suatu bisnis adalah jika IRR lebih besar dari DF. Dari hasil perhitungan. IRR Telur asin H-Organik" $>$ DF yaitu $35,29 \%>20 \%$. sehingga menurut IRR usaha ini layak untuk dikembangkan.

Analisa SWOT total perusahaan Telur asin H-Organik sebagai berikut:
1. Kekuatan

a. Perusahaan menggunakan bahan baku yang berkualitas sehingga menghasilkan produk yang berkualitas.

b. Perusahaan tidak menggunakan bahan pengawet atau kimia yang membahayakan kesehatan konsumen.

c. Adanya kenaikan penjualan dari tahun ke tahun akan meningkatkan laba perusahaan.

d. Harga jual produk bersaing sesuai dengan kualitas produk.

e. Lokasi pabrik strategis dan cukup luas. karena berada di

ISSN: 2355-0295, e-ISSN: 2549-8932

http://ejournal.bsi.ac.id/ejurnal/index.php/ecodemica 
pinggir jalan raya sehingga mudah dijangkau dengan berbagai alat transportasi.

f. Perusahaan telah memiliki suratsurat perizinan sebagai kelengkapan legalitasnya.

g. Adanya sistem pengawasan langsung oleh pemilik perusahaan yang bersamaan dengan kegiatan. dimana suatu aspek dari prosedur harus memenuhi syarat atau atura tertentu guna menjamin ketepatan dan kelancaran pelaksanan proses produksi.

h. Proses produksi yang dilakukan oleh perusahaan tidak menghasilkan limbah yang dapat membahayakan lingkungan sekitar.

i. Perusahaan telah membantu pemerintah dalam mengurangi jumlah pengangguran dan meningkatkan taraf hidup masyarakat sekitar.

2. Kelemahan

a. Desain kemasan yang kurang menarik

b. Belum tersedianya teknologi yang memadai/canggih.

c. Masih menggunakan manajemen tradisional dan akuntansi yang sangat sederhana

d. Perencanaan strategis dan operasional yang belum matang dan mantap. sehingga belum maksimal bahkan tidak terencana dengan baik.

e. Kurangnya pengetahuan manajemen mengenai UU Ketenagakerjaan. mengenai etika bisnis dan perdagangan pasar global.

3. Peluang

a. Adanya volume penjualan yang mengalami peningkatan dari tahun ke tahun sehingga akan meningkatkan laba perusahaan.

b. Adanya peluang untuk memperluas pasar ke wilayah luar Bandung

c. Adanya kepercayaan konsumen terhadap perusahaan karena perusahaan telah memenuhi unsure legalitas yang diperlukan dalam pendirian suatu usaha dan produk.

d. Tidak adanya pencemaran yang ditimbulkan atau keluhan dari masyarakat sekitar akibat adanya kegiatan produksi yang dilakukan oleh perusahaan.

e. Adanya investor atau bank yang akan memberikan pinjaman modal kepada perusahaan untuk mengembangkan usaha.

4. Ancaman

a. Mudahnya teknik pembuatan telur asin menyebabkan banyak pesaing muncul.

b. Ketidakstabilan ekonomi mengkhawatirkan permintaan akan menurun sedangkan bahan baku terus mengalami kenaikan.

c. Adanya kemungkinan pesaing yang menggunakan teknik atau proses produksi yang lebih baik sehingga dapat menghasilkan produk yang lebih berkualitas dengan harga yang lebih murah serta dapat memproduksi dalam kapasitas yang lebih besar.

d. Adanya perencanaan yang lebih baik. manajemen yang professional serta sistem akuntansi yang baik dan benar dari perusahaan pesaing yang sejenis sehingga lebih cepat untuk mengembangkan usahanya.

\section{PENUTUP}

Berdasarkan kesimpulan dalam penelitian ini dilihat dari aspek 
pemasaran. Ramalan permintaan pasar terhadap telur asin setelah dianalisis, ternyata permintaan pasar sangat fluktuatif. Begitu juga dengan potensi pasar yang ternyata menunjukkan adanya permintaan yang belum terpenuhi oleh perusahaan. Dengan demikian perusahaan berkesempatan untuk dapat meningkatkan kapasitas produksinya serta menambah toko distribusi penjualan. Lokasi yang cukup strategis memungkinkan perusahaan untuk dapat meningkatkan efisiensi. melalui pengelolaan bahan baku. serta mengelola ketersediaan tenaga kerja yang merupakan keuntungan bagi perusahaan Telur asin H-Organik. Adanya cabang toko baru sebagai bentuk perluasan proses pemasaran. serta berpengaruh dalam meningkatkan tingkat penjualan layak untuk direalisasikan. Perkembangan yang dihadapai perusahaan, maka sudah seharusnya struktur organisasi dan

system manajemen yang diterapkan harus diperbaiki sehingga sesuai dengan tuntutan perkembangan perusahaan dalam melakukan proses produksi. Perusahaan tidak mengakibatkan atau menghasilkan limbah yang dapat membahayakan masyarakat sekitar sehingga aman bagi lingkungan. Hal ini menambah nilai positif dan pencitraan bagi perusahaan dimata masyarakat. Dengan adanya perijinan dari instansi terkait, maka akan menambah point tersendiri bagi perusahaan. Sehingga menambah kepercayaan masyarakat terhadap perusahaan serta dapat mempermudah akses dalam mendapatkan dana dari lembaga keuangan sangat terbuka lebar untuk memperoleh tambahan modal usaha.

\section{REFERENSI}

Arifudin, O. (2020). Analisis Budaya Organisasi Dan Komitmen Organisasi Karyawan Bank Swasta Nasional Di Kota Bandung. Jurnal Ilmiah MEA (Manajemen, Ekonomi, Dan Akuntansi), 4(2), 73-87.

http://journal.stiemb.ac.id/index.ph $\mathrm{p} / \mathrm{mea} /$ article/view/327/150

Arifudin, O. (2019). Pengaruh Kompensasi Terhadap Kinerja Karyawan Di PT. GLOBAL (PT.GM). Jurnal Ilmiah MEA (Manajemen, Ekonomi, \& Akuntansi), 3(2), 184-190. http://journal.stiemb.ac.id/index.ph p/mea/article/view/243/90

Arifudin. O. \& Rusmana. F. (2020). Pengaruh Penempatan Karyawan Terhadap Efektivitas Kerja Pada PT Agro Bumi. Value: Jurnal Manajemen Dan Akuntansi, 15(2), 14-21. https://ejournal.umc.ac.id/index.php/VL/art icle/view/1091/764

Brent, D. R. dan L. P. S. (2013). Komunikasi dan Perilaku Manusia. Jakarta: PT RajaGrafindo Persada.

DH, B. S. (2009). Manajemen Penjualan. Yogyakarta : BPFE.

Echo Perdana Kusumah, Disman, H. H. (2020). Keterlibatan Merek terhadap Kepuasan dan Niat Berkunjung Kembali Konsumen Resort Terpadu. Jurnal Ecodemica, 4(1), 135-145. https://ejournal.bsi.ac.id/ejurnal/in dex.php/ecodemica/article/view/78 80 
Jakfar, K. \&. (2012). Studi Kelayakan Bisnis. Cetakan ke Delapan. Jakarta: Kencana.

Philip, K. (2005). Manajemen Pemasaran (terjemahan). Jakarta: Prentice Hall.

Sunyoto, D. (2014). Dasar-Dasar Manajemen Pemasaran (Konsep, Strategi, dan Kasus). Cetakan ke-1. Yogyakarta: CAPS (Center for Academic Publishing Service).

Westwood, J. (2006). How to write marketing plan. Jakarta: PT Elex Media Komputindo.

\section{BIODATA PENULIS \\ Opan Arifudin}

Dosen Tetap STEI Al-Amar Subang. Lulus S1 Pendidikan Agama Islam (2014), Program Magister Manajemen Pendidikan Universitas Islam Bandung (2017), dan Kandidat Program Doktor Universitas Nusantara (2019). Penulis berlisensi Badan Nasional Standarisasi Profesi (BNSP) dengan nomor Penulis BNSP 1446.020612019. Dengan Google Scholar ID DSxAzyQAAAAJ dan ID Sinta 6709823.

\section{Yayan Sofyan}

Dosen Tetap STIE Muhammadiyah Bandung (D/h Universitas Muhammadiyah Bandung). Lulus S1 Ilmu Manajemen, STIE STEMBI Bandung (2014), Program Magister Manajemen STIE Pasundan Bandung (2016), dan Kandidat Program Doktor Universitas Nusantara (2019) dengan Google Scholar ID TQiNZVMAAAAJ\&hl serta ID Sinta 6201636.

\section{Rahman Tanjung}

Dosen Tetap STIT Rakeyan Santang Karawang. Lulus S1 Fakultas Ekonomi Jurusan Manajemen UNSOED Purwokerto, Magister Manajemen Konsentrasi MSDM STIE Kampus Ungu Jakarta dan saat ini sedang menempuh studi doktoral di Universitas Islam Nusantara (UNINUS) Bandung dengan Google Scholar ID Jo6GAGUAAAAJ\&hl=en serta ID Scopus 57217086407. 